\title{
Women in Fisheries and Aquaculture in Nigeria: Introducing the Bootstrap in the Roadmap
}

\author{
Francis M. Nwosu ${ }^{1, *}$, Kafayat A. Fakoya ${ }^{2}$, Shehu L. Akintola ${ }^{2}$, Ayojesutomi O. Abiodun-Solanke ${ }^{3}$ \\ ${ }^{1}$ Department of Biological Oceanography, Faculty of Oceanography, University of Calabar, PMB 1115 Calabar, Cross River State, \\ Nigeria. \\ ${ }^{2}$ Department of Fisheries, Faculty of Science, Lagos State University, Ojoo, Lagos State, Nigeria. \\ ${ }^{3}$ Department of Fisheries Technology, Federal College of Fisheries and Marine Technology, Victoria Island, Lagos, Nigeria.
}

\begin{abstract}
How to cite this paper: Francis M. Nwosu, Kafayat A. Fakoya, Shehu L. Akintola, Ayojesutomi O. Abiodun-Solanke. (2021) Women in Fisheries and Aquaculture in Nigeria: Introducing the Bootstrap in the Roadmap. International Journal of Food Science and Agriculture, 5(4), 570-573. DOI: $10.26855 /$ ijfsa.2021.12.002
\end{abstract}

Received: August 11, 2021

Accepted: September 3, 2021

Published: October 12, 2021

*Corresponding author: Francis $\mathrm{M}$. Nwosu, Department of Biological Oceanography, Faculty of Oceanography, University of Calabar, PMB 1115 Calabar, Cross River State, Nigeria. Email: fmnwosu@yahoo.com

\begin{abstract}
Nigeria's fisheries sector is gender biased in terms of prominence in participation. The male counterparts dominate the scene, occupying prominent positions such as ownership, control and access to productive resources of aquaculture production systems, ownership of the fishing vessels and equipment in the capture fisheries sector. These roles confer on them pecuniary benefits such as investment opportunities, loan facilities, importing and exporting licences, among others. Despite women's economic potentials in small-scale fisheries and aquaculture, investments by women in both the aquaculture, artisanal and industrial sectors are at abysmally low levels. The female counterparts play the second-fiddle role of processing and marketing while depending on the male counterparts for major decisions. Underlying socio-cultural norms and gender relations accentuated by intersectionality are factors which most often impede the opportunities to own, access to or control productive resources and other inputs. Apparently, gender mainstreaming in the fisheries sector is very nascent in Nigeria. Our objective in this review is to re-orient women particularly in the small-scale fisheries sector including capture and aquaculture for active and strong participation in ownership, productivity and policy/decision making contributions. Secondary data and inferences from previous studies, particularly reports and reviews from across the globe were compared with what is obtainable in Nigeria. We therefore propose improving social-entrepreneurship, bootstrapping and social-capital based empowerment initiatives among other interventions that would boost women's participation in Nigeria's fisheries sector.
\end{abstract}

\section{Keywords}

Fisheries, Aquaculture, Women, Gender, Nigeria

\section{Introduction}

The duo of small-scale fisheries and aquaculture are enormous contributors to food fish, income and employment to numerous households and also empower women around the world. Kawarazuka and Béné [1] noted the link between the two sectors of every national economy and nutritional security. On nutritional security, fish and fishery products are known to provide the cheapest source of animal protein as they are available to varying purchasing powers of the populace based on size and quantity.

The main sources of fish are artisanal fisheries, industrial fisheries, importation and aquaculture. In Nigeria, fish from both sectors of capture and culture fisheries contributed about 2\% of national Gross Domestic Product (GDP) and 40\% of the animal protein intake in 2014, while the artisanal fisheries sector, in particular, is reputed to employ about three 
million people [2].

With an estimated population of about 180 million, Nigeria needs 3.32 million metric tonnes of fish to keep a healthy society. Of this national fish demand, domestic production from all fisheries was 1.123 million metric tonnes as in 2014 [3]. The gap between demand and supply has encouraged huge importation to make up for the deficit. For instance, about 2 million metric tonnes was imported in 2015 alone [4]. As capture fisheries continue to decline globally, aquaculture remains the hope for realizing sustainable food fish supply.

Olagunju, et al. [5] noted that fish farming or aquaculture in Nigeria started effectively over 50 years ago. However, Nigeria has yet to realize her full potentials in fish production necessary for meeting domestic demand. Although absolute figures of production, import and contributions by the various fisheries sector may differ based on author perception, there is a consensus of the urgent need to increase domestic production of food fish [6-8]. According to reference [9], the major challenges to sustainably increasing food fish production in Nigeria remain the unavailability of credit facility and other incentives, poor extension services, and lack of improved policies and legal framework.

The involvement of women in fisheries value chains is characterized by low capital and technology input. It is estimated that out of the total population depending on capture fisheries, 47 per cent are women [10]. The female workforce, particularly in the small scale fisheries sector tends to be high. In aquaculture, one of the fastest growing primary production sectors, women's contributions are increasing proportionately.

Women contribute significantly to the national economies through their participation in agricultural production, processing and marketing, yet more than 60 percent of the world-poor are women and they have fewer options than men to escape poverty [11].

One of such areas that require addressing is the creation of gender-friendly opportunities that would be void of inequity and ensure deliberate level-playing field for the female gender. We posit for expansion of the female gender roles in small-scale fisheries and aquaculture in Nigeria, beyond what [12] and [13] referred to as "gender-segregated division of labour" in the fisheries sector. This would increase women's options to escape poverty [11].

\section{Materials and Methods}

In this study, we used frame survey, field observations, structured interview using questionnaire in focus group discussion-setting and community-relations key informants. Case studies covering selected sections of the Nigerian nation, namely; Cross River, Akwa Ibom, and Lagos States, were considered a representation of the situation on ground. We sought to know what roles women played in the aquaculture ventures and small-scale fisheries in the area. Questions on ownership, access to resources, decision-making/policy, and their concerns were discussed [14]. The interviews and discussions were held in huts, jetties and landing ports at fishing settlements and beach markets, as well as fish farm locations in communities in Cross River, Akwa Ibom and Lagos States of Nigeria. We also reviewed available literature and extracted secondary data for evaluation.

\section{Results}

Our results showed similar trends in both aquaculture and the small-scale fisheries sectors. In the aquaculture sector, women did not own farms, except for joint-family ventures. Even at that, their participation was limited. In the small-scale fisheries sector, women played greater role. The fishery on gastropod and bivalve molluscs was exclusively for women, whose exploitation is by gleaning (also referred to as hand-picking in [15]). In addition to gleaning of edible molluscs, women were also responsible for the processing and marketing of harvested fish, constituting what are known in local parlance as fish mongers [16-18]. Women did not own fishing boats/canoes, fishing nets and other fishing equipment/gear. However, women could be financiers [19] or subsidize the acquisition of these facilities in exchange for reduced-price for landed catches or harvested products.

\section{Discussion and Conclusions}

It is well-known fact that Nigeria has been operating a monolithic, oil-dependent economy, until recently. Successive governments had attempted a diversification without much success. One of the pitfalls was access to credit. Until recently, national policies on credit to farmers have not been friendly to fish farmers in general, but essentially biased towards women. However, consecutive administrations have modified credit policies to be more gender sensitive, allowing women access without the apron-string of male counterparts; that is, equal opportunity.

The Central Bank of Nigeria (CBN) has introduced a programme of financial lifeline for different categories of farmers, including aquaculture. This programme is dubbed "Anchor Borrowers' Scheme" [20]. Flagged-off in November, 2015, the scheme is designed not only to increase agricultural production in Nigeria, but also to create linkages between production and consumption.

As this intervention policy programme is at the take-off stage, it is imperative for women to take advantage and build 
sustainable structures. Women should take initiative; invest and grow the fisheries/aquaculture business; take responsibilities and define roles for themselves; should not rely on men or wait for assigned roles. It is also at this take-off stage that budding women-entrepreneurs are encouraged to organize into social networks and cooperative societies for mutual benefits.

Women are also encouraged to maximize their entrepreneurial potentials in the fisheries sub-sector of the economy through social capital. Among the Ibaka women fish traders in Akwa Ibom State, Ibrahim, et al. [21] noted that social capital was a successful livelihood strategy to cope with lack of financial assistance and market information, adding that competence in the trade is positively influenced more by the ability to establish networks of trust.

Despite so many benefits and potentials, some women do not belong to any cooperative due to ignorance of the contribution of membership to their economic activities or lack of access to knowledge on the formation and involvement in fisheries co-operatives or informal associations [22-23]. It is also apparent that with membership of fisheries cooperatives, women still tend to have lower accessibility to productive resources than their men counterparts. For instance, a comparison of women in female-only and mixed gender cooperatives, associations or groups showed that fewer women harness the opportunity of cooperative membership to fund their fisheries business [24-26].

Taking cue from a study on the fisher-folks of Jebba Lake basin, social capital is good entry point for policy advocacy and intervention. Options for improving the functionalities or workings of cooperatives are not far-fetched. Cooperatives must be truly gender responsive otherwise, attainment of equal opportunity between men and women will remain elusive [27]. Improved policy formulation to enhance gender mainstreaming in various government interventions must be pursued [26]. A glance at FMARD [28] showed that specific plans of action within government documentation for addressing gender disparities in the Fisheries Sector are tailored towards empowerment of women in aquaculture, one of the selected priority value chains targeted for development.

Nigerian women are encouraged to maximize the policy interventions currently available, network and organize into cooperatives, invest and grow the business; take responsibilities and define roles for themselves; and abandon the sociocultural norm of relying on male folk for leadership.

\section{Acknowledgements}

We acknowledge the fishing communities and owners of the various aquaculture facilities visited for their cooperation. We also thank the Field Assistants who assisted with communication in local languages when it was necessary.

\section{References}

[1] Kawarazuka, N. and C. Béné. (2010). Linking small-scale fisheries and aquaculture to household nutritional security: an overview. Food Security, 2(4): 343-357.

[2] Ozigbo, E., Anyadike, C., Adegbite, O., and P. Kolawole. (2014). Review of Aquaculture Production and Management in Nigeria. American Journal of Experimental Agriculture, 4(10): 1137-1151.

[3] FCWC (Fishery Committee for the West Central Gulf of Guinea). (2016). Nigeria’s fishery statistics-2016 Summary Report. https:/www.fcwc-fish.org/fisheries/statistics/nigeria/901-nigeria-fishery-statistics-2016-summary-report (Accessed July 18, 2018).

[4] Ajimotokan, O. (2018). FG Declares 2.1m Metric Tonnes of Fish Supply Gap. https://www.thisdaylive.com/index.php/ 2018/03/21/fg-declares-2-1m-metric-tonnes-of-fish supply-gap/ (Accessed August 13, 2018).

[5] Olagunju, F. I., Adesiyan, I. O., and A. A. Ezekiel. (2007). Economic viability of Cat fish production in Oyo state, Nigeria. J. Hum. Ecol., 2007, 21(2): 121-124.

[6] FDF (Federal Department of Fisheries). (2008). Federal Department of Fisheries, Fisheries Statistics of Nigeria Projected human population; fish demand and supply in Nigeria, 2000-2015, p. 56.

[7] Akintola, S. (2014). Fisheries and aquaculture: Options and pathway to providing more fish in Nigeria. http://thenationonlineng.net/fisheries-and-aquaculture-options-and-pathway-to-providing-more-fish-in-nigeria/ (Accessed August 13, 2018).

[8] NBS (National Bureau of Statistics). (2017). Nigeria’s fish production: 2010-2015. https://www.proshareng.com/admin/upload/ reports/NigeriaFisroductioessed.pdf. (Accessed August 12, 2018).

[9] Fakoya, K. A., Owodeinde, F. G., Jimoh, A. A., and S. L. Akintola. (2004). An overview of the challenges and prospects in developing an aquaculture industry in Lagos State, Nigeria. Proceedings of the 19th Annual Conference of the Fisheries Society of Nigeria (FISON), pp. 500-510.

[10] Adewumi, A. A. (2015). Aquaculture in Nigeria: Sustainability issues and challenges. Direct Research Journal of Agriculture and Food Science, 3(12): 223-231. 
[11] Ajani, O. I. (2009). Gender Dimensions of Agriculture, Poverty, Nutrition and Food Security in Nigeria. International Food Policy Research Institute (IFPRI), Series 5, 2009.

[12] Weeratunge, N., Snyder, K. A., and C. P. Sze. (2010). Gleaner, fisher, trader, processor: Understanding gendered employment in the fisheries and aquaculture sector. Paper presented at: Workshop on gaps, trends and current research in gender dimensions of agricultural and rural employment: differentiated pathways out of poverty. Rome, 31 March-2 April, 2009. https://onlinelibrary.wiley.com/doi/abs/10.1111/j.1467-2979.2010.00368.x., Accessed July 18, 2018.

[13] FAO. (2015). A review of women's access to fish in small-scale fisheries, by Angela Lentisco and Robert U., Lee. Fisheries and Aquaculture Circular, No. 1098. Rome, Italy.

[14] Cliffe, P. T. and O. A. Akinrotimi. (2015). Role of Women in Fishery Activities in Some Coastal Communities of Rivers State, Nigeria. International Journal of Agricultural Research, 10: 24-32.

[15] Holzlöhner, S., Nwosu, F. M., and U. I. Enin. (2004). Fishing effort statistics of the artisanal fisheries of the Cross River Estuary, Nigeria. Global Journal of Pure and Applied Sciences, 10(2): 249-256.

[16] Ekpo, I. E. (2013). Women’s Participation in Lower Ikpa River Fisheries of AkwaIbom State, Nigeria: A Case Study of Ifiayong. Journal of Fisheries and Aquatic Science, 8: 268-276.

[17] Nwabeze, G. O., Ifejika, P. I., Tafida, A. A., Ayanda, J. O., Erie, A. P., and N. E. Belonwu. (2013). Gender and Fisheries of Lake Kainji, Nigeria: A Review. Journal of Fisheries and Aquatic Science, 8: 9-13.

[18] Dambatta, M. A., Sogbesan, O. A., Fagge, A. U., Dutse, S. I., and A. U. Shuaibu. (2016). Role of Women in Fisheries and Aquaculture in Kano State, Nigeria. Journal of Biology, Agriculture and Healthcare, 6(14). https://iiste.org/Journals/index.php/ JBAH/article/viewFile/31866/32736. (Accessed August 14, 2018).

[19] Overa, R. (2003). Gender Ideology and Manoeuvring Space for Female Fisheries Entrepreneurs. Research Review NS, 19.2, 49-66.

[20] CBN (Central Bank of Nigeria). (2016). Anchor Borrowers’ Programme Guidelines. P. 19. https://www.cbn.gov.ng/out/2017/ dfd/anchor\%20borrowers\%20programme\%20guidelines\%20-dec\%20\%202016.pdf. (Accessed August 05, 2018).

[21] Udong, E., Niehof, A., and A. Van Tilburg. (2009). Struggle for Survival: Women fish traders fighting institutional and cultural constraints in fishing communities in the Niger Delta, Nigeria. Paper presented at the Conference on International Research on Food Security, Natural Resource Management and Rural Development. Tropentag 2009, University of Hamburg, October 6-8, 2009.

[22] Ibrahim, H. I., Kigbu, A. A., and R. Mohammed. (2011). Women's experiences in small scale fish processing in Lake Feferuwa fishing community, Nasarawa State, Nigeria. Livestock Research for Rural Development. Volume 23, Article \#42. Retrieved August 11, 2018, from http://www.lrrd.org/lrrd23/3/ibra23042.html.

[23] Odebiyi, O. C., George, F. O. A., Odulate, D. O., Agbonlahor, M. U., and O. J. Olaoye. (2013). Value-Chain Analysis for Coastal Fisheries Development in Nigeria. Global Journal of Science Frontier Research Agriculture and Veterinary, Volume 13 Issue 11 Version 1.0. https://journalofscience.org/index.php/GJSFR/article/download/954/819/ Accessed August 14, 2018.

[24] Omotoso, F. O. and A. G. Daramola. (2005). Institutional and non-Institutional credit supply services to Fisher-Women in coastal fishing communities of South-western Nigeria: An empirical survey. Journal of Agriculture and Social Research, 5(1): 73-80.

[25] Akinpelu, O. M., Ayeloja, A. A., George, F. O. A., Adebisi, G. L., and Jimoh, W. A., et al. (2013). Gender Analysis of Processing Activities among Commercial Catfish Processors within Ibadan Metropolis, Oyo State South-Western Nigeria. J Aquac Res Development, 4: 176. doi:10.4172/2155- 9546.1000176.

[26] Akinpelu, O. M., Ayeloja, A. A., George, F. O. A., Adebisi, G. L., and Jimoh, W. A., et al. (2013). Gender Analysis of Processing Activities among Commercial Catfish Processors within Ibadan Metropolis, Oyo State South-Western Nigeria. J Aquac Res Development, 4: 176. doi: 10.4172/2155- 9546.1000176.

[27] Nippierd, A. B. (2002). Gender issues in cooperative. https://www.aciamericas.coop/IMG/pdf/genderissues.pdf.

[28] FMARD. (2016). The Agriculture Promotion Policy (2016-2020): Building on the Successes of the ATA, Closing Key Gaps. Policy and Strategy Document. P. 59. 